\title{
A NEW SPECIES OF HALIPLUS
}

\author{
By Edith W. MANK
}

Lawrence, Mass.

Some beetles, collected in July 1939 in Churchill, Manitoba by Mr. Albert L. Wilk, came into the hands of Dr. H. C. Fall and were mounted just before his death. He had examined them and noted among them two possible new species, one a Hydroporus and the other a Haliplus. He mentioned to me particularly the Haliplus. This, I herewith wish to describe and name for him in recognition of his unfailing inspiration and help.

Both Dr. P. J. Darlington, Jr. and Mr. J. B. Wallis have most generously given their time and assistance in preparing this description.

\section{Haliplus falli n.sp.}

Holotype o: Length $2.79 \mathrm{~mm}$. Width $1.44 \mathrm{~mm}$. In general form narrower and more parallel than longulus to which this species runs in the key to the Haliplids by Mr. Wallis.

Head: Brownish yellow with posterior part dusky; mouth parts and antennæ the same color as the front. Surface alutaceous, making it duller than in such species as longulus. A punctate triangular area with base of triangle anterior, between the antennæ; also punctured areas in crescent shape around the eyes; also on posterior darkened part of the head. Smooth area, shiny not alutaceous, between the clypeus which is punctured, and the punctured area on the front. Width between the eyes half the entire width of the head. Head wider, as compared with the base of the pronotum, than in longulus.

Pronotum: More yellowish than the head, with basal area dark. The dark area widest between the fairly long, deep, longitudinal plicae. Also darkened medially on the anterior edge. Surface very finely alutaceous. Lateral margin nar- 
row. In the holotype and in all but one of the specimens examined, this margin is continuous with the edge of the elytra. In one of the base of the pronotum is slightly wider than the base of the elytra. Relatively few rather large punctures in the widest part of the dark area at the base between the plicae; disc and lateral areas with a few shallow, scattered punctures. Disc more flattened than in longulus. Pronotum narrowed toward the apex but less so than in longulus, making the apex greater in width compared with the base than in longulus. The apex of the pronotum is also slightly wider than the widest part of the head.

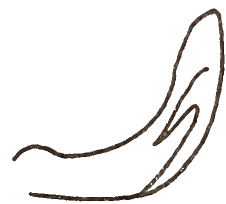

1

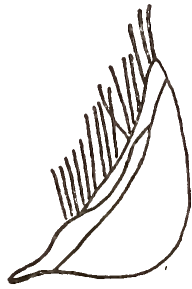

2

Fig. 1. Haliplus falli n. sp., adeagus; Fig. 2, left paramere.

Elytra: Yellowish with black maculation consisting of a post medial sutural triangular blotch that reaches a point between the second and third striae; less definite dark markings in the form of darkened striae on the third and fourth striae posterior to the blotch; and also on the fifth and sixth striæ opposite the posterior part of the sutural blotch. Surface definitely alutaceous in the $q$. In the $\hat{o}$ the surface is extremely minutely punctulate and alutaceous. Punctures forming striæ spaced well apart and on the whole about as deep as on the basal part of the pronotum. Apices of the elytra not sinuate. Body narrower than in longulus and more parallel, widest only a little in front of middle.

Prosternum: Prosternal process narrowest between the anterior part of the fore coxæ; sides margined; medial area not furrowed, slightly convex with relatively few large punctures; surface alutaceous. 
Metasternum: Smooth at middle; margined with a very fine bead between the middle coxæ; on either side behind the middle coxæ, a group of more or less confluent large punctures, appearing at first glance to form a depression in the position of the furrows in longulus.

Abdomen: Ventral surface strongly alutaceous throughout.

Claws: Practically equal in length on the front tarsi.

Allotype ô: Post-medial sutural blotch somewhat larger than in the holotype. Also, as indicated above, surface of elytra extremely minutely punctulate and alutaceous. Front and middle tarsi with the usual pubescence on the underside of the first three tarsal segments. Claws of the anterior tarsi nearly equal, the anterior slightly shorter and more curved. Ventral surface of the abdomen alutaceous at sides except for the last segment which is alutaceous throughout.

The genitalia are as shown. The left paramere with hairs rather sparsely placed along nearly the entire length of the side. The ædeagus evenly curved, not narrowed apically as in longulus.

The o holotype is in the Fall collection at the Museum of Comparative Zoology at Cambridge as well as one $q$ and one $\hat{o}$ paratype. The of allotype is in the collection of Mr. J. B. Wallis while three paratypes, two o and one $\hat{o}$ are in the author's collection.

Of the Haliplidx with basal pronotal plicæ, this new species most closely resembles $H$. longulus. It is like longulus in the length of the plicæ, in the width of the side margins of the pronotum, in the fact that usually the edge of the pronotum is continuous with that of the elytra, and in the lack of a channel on the prosternal process.

It differs from longulus, in that the head is wider, the apex of the pronotum is wider compared with the base of the pronotum, the body is more narrow and parallel, the surface of the elytra is definitely alutaceous in the $q$ and extremely minutely punctulate and alutaceous in the $\hat{o}$ and therefore not shiny, the metasternum has a fine marginal bead between the middle coxæ, and the claws of the front tarsi of the $\hat{o}$ are less differentiate than in longulus.

All specimens examined were from Churchill, Manitoba. 


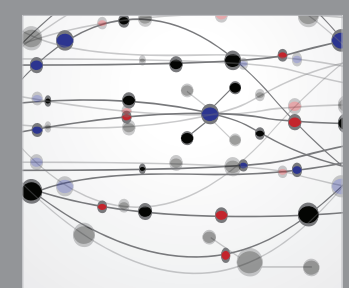

The Scientific World Journal
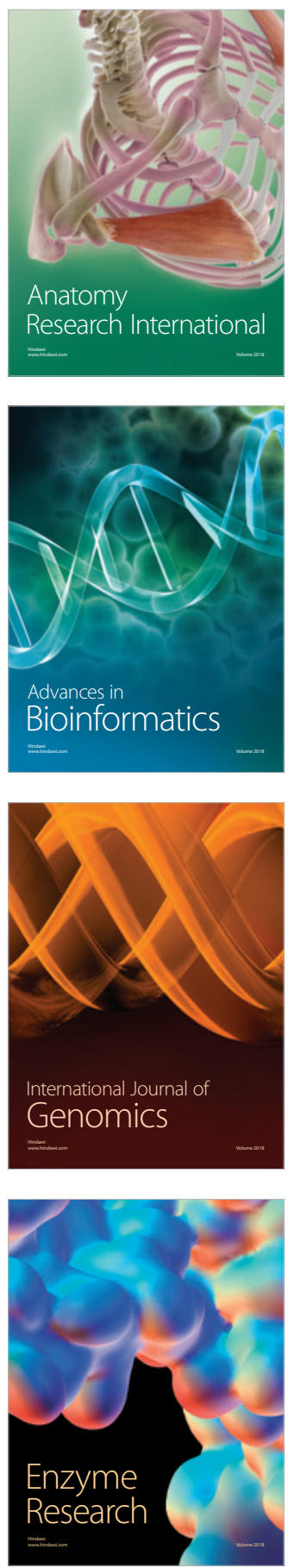
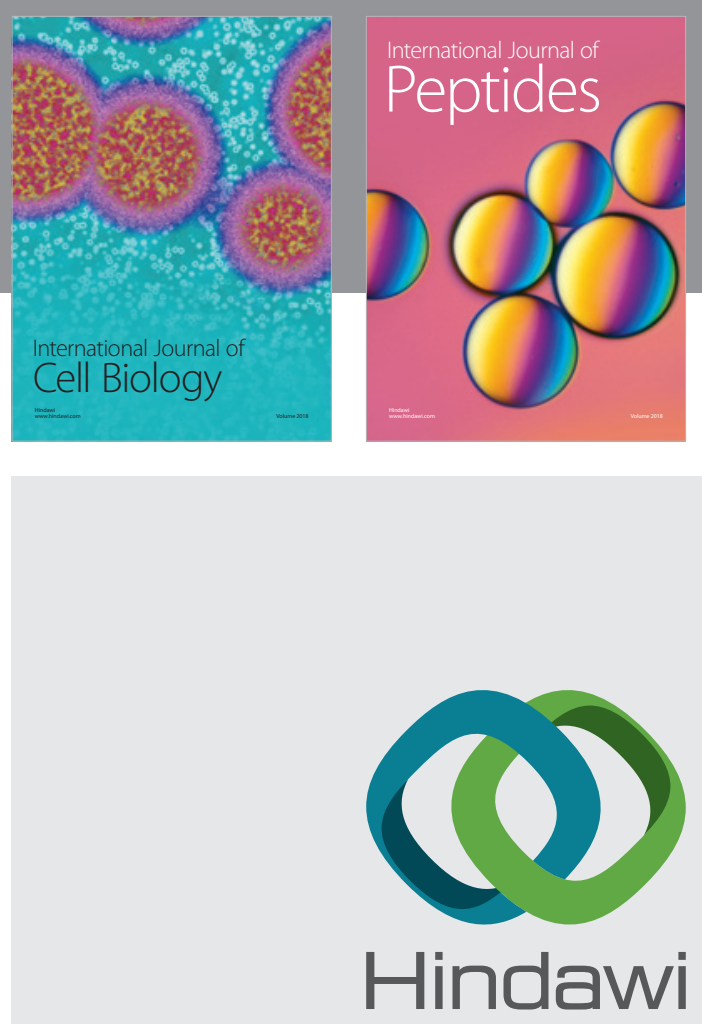

Submit your manuscripts at

www.hindawi.com
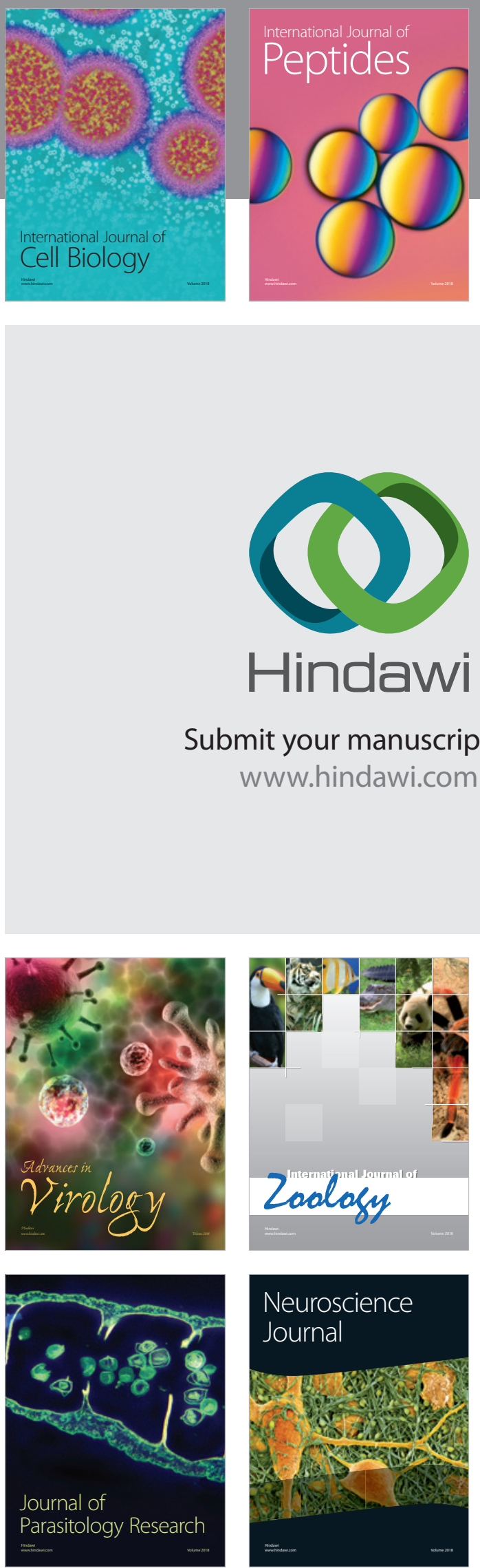
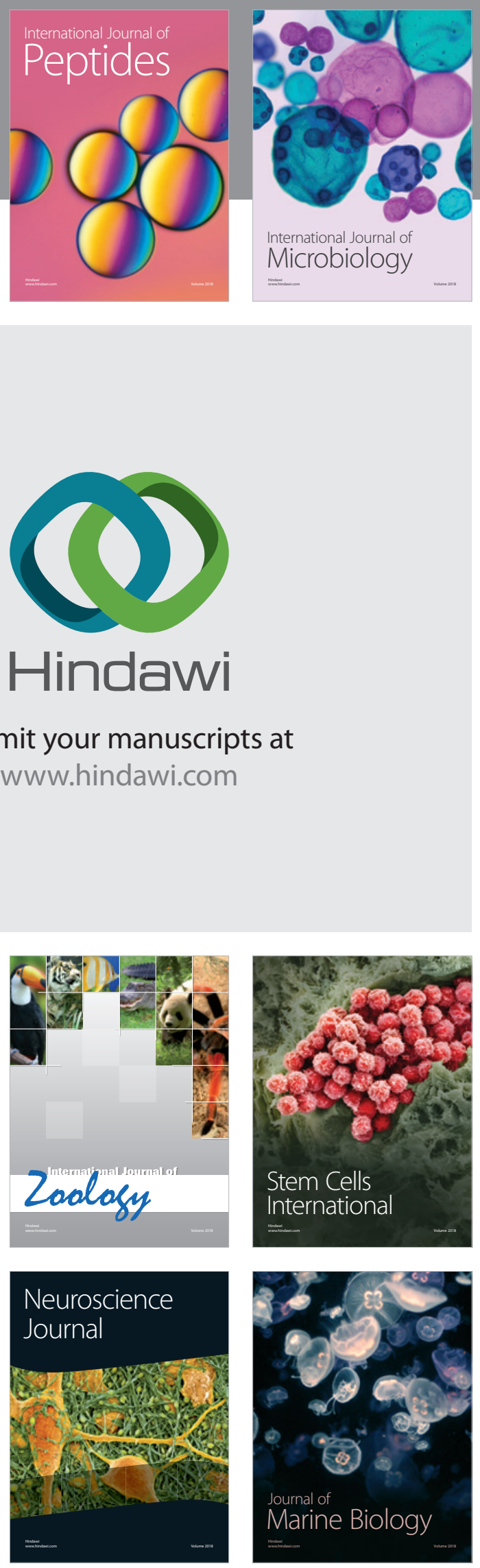
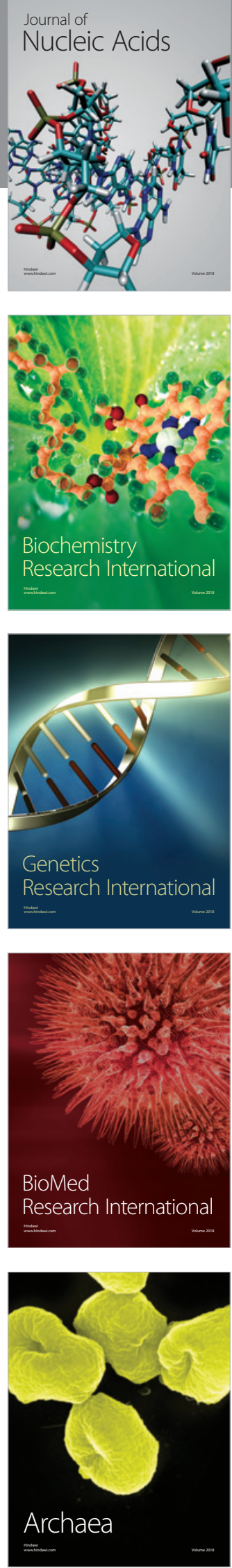